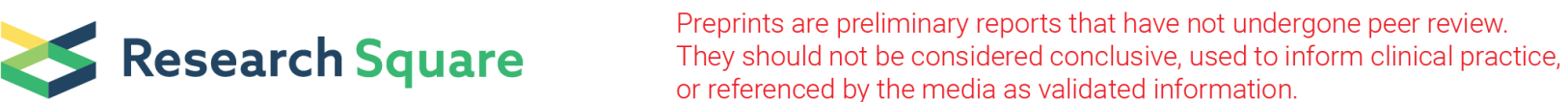

\section{Cardiovascular Implications of Coronavirus Disease 2019 (COVID-19): A Systematic Review}

Ravi Ranjan Pradhan ( $\sim$ drravipradhan@iom.edu.np)

Provincial Hospital, Province-2, Janakpurdham, Dhanusha, Nepal https://orcid.org/0000-0003-4425-3029

Ajay Kumar Yadav

Provincial Hospital, Province-2, Janakpurdham, Dhanusha, Nepal

Shobha Mandal

Robert Packer Hospital, Sayre, Pennsylvania, USA

\section{Systematic Review}

Keywords: Coronavirus disease-2019, COVID-19, Cardiovascular implications, Acute cardiac injury, Death

Posted Date: July 6th, 2020

DOI: https://doi.org/10.21203/rs.3.rs-39929/v1

License: @ (i) This work is licensed under a Creative Commons Attribution 4.0 International License. Read Full License 


\begin{abstract}
Background: World Health Organization has declared Coronavirus disease (COVID-19) as a Public Health Emergency of International Concern. It has killed thousands and millions are infected worldwide. Though COVID-19 is supposed to be primarily a disease of respiratory system, it also has widespread implications on other systems as well. The aim of this systematic review is to summarize the cardiovascular implications of COVID-19.
\end{abstract}

Methods: PubMed, PubMed Central, EMBASE, and Google Scholar were searched for peer-reviewed articles which aimed to delineate the cardiovascular implications of COVID-19.

Results: A total of six articles (five original articles and one case report) were included. We found diverse cardiovascular implications of CoVID-19 ranging from acute cardiac injury to death. New onset abnormalities in electrocardiogram or echocardiogragram, elevated plasma levels of cardiac troponin, NTproBNP, and D-dimer have role in early identification of acute cardiac injury in such patients. Additionally, cardiac troponin and NT-proBNP can be used to evaluate prognosis and possible need for intensive care in these patients.

Conclusion: Acute cardiac injury is common in patients with COVID-19. Aggressive supportive management based on prognostic indicators along with management of heart failure, arrhythmias, acute coronary syndrome and thrombosis can improve clinical outcomes in such patients.

\title{
Introduction
}

In late 2019, a cluster of cases of 'pneumonia of unknown origin' emerged which was linked to seafood wholesale and wet market in Wuhan, China (1), that heralded the onset of Coronavirus disease (COVID-19). The disease has now spread rapidly to several countries around the globe and has already been declared a pandemic by WHO (2). Till April 8, 2020, a total of 1,441,589 confirmed cases of COVID-19 with mortality of 82,933 have been reported (2). COVID-19 is probably the greatest threat to mankind of $21^{\text {st }}$ century that has not only challenged the current medical practices, but also has imposed a huge psychological and socio-economic burden to the entire world.

Coronavirus is one of the major pathogens that primarily target the human respiratory system (3). However, previous outbreaks of coronaviruses i.e. severe acute respiratory syndrome (SARS) and the Middle East respiratory syndrome (MERS) have already shown multisystem involvement including cardiovascular system as well (4-6). Given that, with increasing number of confirmed cases and death due to COVID-19, it is important to be acquainted with cardiovascular manifestations induced by this viral infection. However, there is only limited published data pertaining to cardiovascular presentations of COVID-19. The present systematic review aims to describe the cardiovascular implications of COVID-19 and fill the gap in the knowledge regarding understanding of varied cardiovascular manifestations of COVID-19.

\section{Methods}

\section{Protocol and registration}

We followed the recommendations established by the Preferred Reporting Items for Systematic Reviews and Meta-Analyses (PRISMA) statement (7). The systematic review protocol was not registered due to the urgency of the matter and very limited available evidence on the topic.

\section{Eligibility criteria}

Published peer-reviewed articles from January 1, 2020 until March 30, 2020 which aimed to assess cardiovascular implications in patients with COVID-19 were included. Article language restrictions were not imposed. In addition to original articles; case reports, and case series were also included. Editorials, letters to editor, and correspondences were excluded.

\section{Search strategy}

We searched standard relevant publications indexed in PubMed, PubMed Central (PMC), EMBASE, and Google Scholar. For COVID-19, we used "Novel coronavirus", "Novel coronavirus 2019”, "2019 nCoV”, "Coronavirus Disease 2019”, "COVID-19", "Wuhan coronavirus," "Wuhan pneumonia," and "SARS-CoV2." For cardiovascular implications, we used "Cardiovascular implications", "Acute myocardial injury", "Acute cardiac injury", "Arrhythmias", "Heart failure”, and "Myocardial infarction". A thorough review of the references revealed further relevant articles.

\section{Study selection and data abstraction}

First of all, we screened articles by title and abstract. Then, we examined full texts of relevant articles for inclusion and exclusion criteria. The data abstraction spreadsheet using Microsoft Excel version 2013 was developed; which included the following information: author, year of publication, journal, and country where the study was done, study design, sample size, baseline characteristics and laboratory parameters of the patients and cardiovascular implications of COVID-19. Any duplicated article was counted as a single article.

\section{Results}


A total of 315 articles were retrieved using the search strategy. After screening by abstract and title, 52 articles were selected for full-text assessment. Of these, 46 articles were excluded as they were not relevant to research aims and objectives [Figure 1].

\section{Study characteristics}

All the studies were conducted in China in 2020 and all of them were original articles except for one case report of Cui, et al. (8). Among the original articles, all were retrospective studies except study by Huang, et al. (9) which was prospective, observational study. All the studies have categorized patients into two groups: non-ICU/non-critical/without myocardial injury/with normal cardiac Troponin group and ICU/critical/with myocardial injury/with elevated cardiac Troponin group. Wang, et al.(10) and Huang, et al. (9) defined acute cardiac injury as blood levels of hypersensitive troponin I above the 99th percentile upper reference limit (>28 pg/mL) or new abnormalities shown on electrocardiography and echocardiography. Xingwei, et al. (11) defined myocardial injury as blood levels of myocardial troponin $\geq 3$ times the upper reference limit (34.2 ng / L). However, Chen, et al.(12) and Guo, et al. (13) defined myocardial injury as serum levels of troponin above the 99th percentile upper reference limit [Table 1].

\section{Baseline characteristics and co-morbidities of the patients}

The median age of the patients in all the studies was above 50 years, except in studies of Huang, et al.(9) (median age; 49 years) and Cui, et al. (8) (patient's age; 55 days). In all studies, patients requiring ICU/critical care or patients with myocardial injury/elevated cardiac Troponin were older comparatively, except in study conducted by Huang, et al.(9) (median ages of patients in non-ICU and ICU groups were same). Male predominance was seen in all studies except studies of Cui, et al. (8) and Guo, et al. (13). All the studies have included the underlying co-morbidities of the patients [Table 2].

\section{Cardiovascular complications associated with COVID-19}

Wang, et al. (10) established that among the 138 patients, acute cardiac injury was seen in 10 (7.2\%), shock in 12 (8.7\%), and arrhythmia in 23 (16.7\%) patients. ICU patients were more likely to have one of these complications than non-ICU patients $(p<0.001)$ [Table 3]. ICU patients demonstrated significantly high levels of creatine phosphokinase myocardial band (CPK-MB), cardiac troponin I (cTnl) and D-dimer. Similarly, number of patients who had procalcitonin levels $>0.05 \mathrm{ng} / \mathrm{mL}$ were more in ICU group compared with non-ICU group (27 [75\%] vs 22 [21.6\%]) [Table 4].

Study conducted by Huang, et al. (9) found that among the 41 patients, acute cardiac injury was seen in five (12\%) and shock in three (7\%) patients. Acute cardiac injury (4 [31\%] vs 1 [4\%]) and shock (3 [23\%] vs zero [0\%]) were seen more commonly in ICU patients compared with non-ICU patients [Table 3]. Besides, ICU patients demonstrated significantly high levels of creatine phosphokinase (CPK), and D-dimer. Number of patients who had procalcitonin levels $>0.05 \mathrm{ng} / \mathrm{mL}$ and cTnl $>28 \mathrm{pg} / \mathrm{mL}$ (99th percentile) were more in ICU group compared with non-ICU group [Table 4].

Similarly, Chen, et al. (12) discovered that among the 150 patients, 22 (7.1\%) patients had acute cardiac injury. In the same study, out of 24 patients in critical group, 15 (62.5\%) had acute cardiac injury and 7 (5.6\%) out of 126 patients in non-critical group had acute cardiac injury and the difference was statistically significant ( $p$-value <0.001) [Table 3]. Hypersensitive C-reactive protein (hs-CRP), N-terminal-pro brain natriuretic peptide (NT-proBNP) and cTnl levels of the patients were significantly higher in critical care cases than in mild cases ( $p$-value $<0.001$ [ [Table 4]. On univariate logistic regression analysis, critical disease status had a significant correlation with age, male gender, elevated NT-proBNP, elevated cTnl, elevated hs-CRP, hypertension, and coronary artery disease (all $\mathrm{p}<0.05)$. Multivariate logistic regression analysis revealed that elevated cTnl $(\mathrm{OR}=26.909,95 \% \mathrm{Cl} 4.086-177.226, \mathrm{p}=0.001)$ and coronary artery disease $(\mathrm{OR}$ $=16.609,95 \% \mathrm{Cl} 2.288-120.577, \mathrm{p}=0.005)$ were the independent risk factors of critical disease status.

In study performed by Xingwei, et al. (11) among the 54 severe/critically severe patients, acute myocardial injury was discovered in 24 (44.4\%) patients while $26(48.1 \%)$ patients died during hospital stay. In-hospital mortality rate was significantly higher in myocardial injury group compared to the group without myocardial injury $[75.0 \%(18 / 24)$ vs. $26.7 \%(8 / 30)$, p-value $=0.001]$. In myocardial injury group, C-reactive protein (CRP) and NT-proBNP levels were also found to be significantly higher than those without myocardial injury (all $p$-value $<0.01$ )

Cui, et al (8) has described a case report of acute cardiac injury in an infant infected with COVID-19 as suggested by elevated plasma levels of CPK-MB, and cTnl.

Guo, et al. (13) discovered that among the 187 patients, 52 (27.8\%) exhibited acute cardiac injury as indicated by elevated cardiac troponin T (cTnT) levels. During hospitalization, arrhythmias were seen in 11 (5.9\%) patients. Patient with elevated cTnT levels had more frequent malignant arrhythmias compared with normal cTnT (9[17.3\%] vs 2[1.5\%]). The overall mortality was $23 \%$ (43 patients died) [Table 4]. The mortalities were $7.62 \%$ (8 of 105), 13.33\% (4 of 30), $37.50 \%$ ( 6 of 16$), 69.44 \%$ (25 of 36) for patients without underlying CVD and normal CTnT levels, with underlying cardiovascular disease (CVD) and normal cTnT levels, without underlying CVD but elevated cTnT levels, and with underlying CVD and elevated cTnT levels respectively. Elevated cTnT levels was seen more commonly in patients with underlying CVD compared with patients without CVD (36 [54.5\%] vs 16 [13.2\%]). A significant positive linear correlation of plasma cTnT levels with plasma hsCRP levels $(\beta=0.530, p<.001)$ and NT-proBNP levels $(\beta=0.613, p<.001)$ was also observed.

\section{Discussion}

In previous outbreaks of influenza and coronavirus i.e. MERS and SARS coronavirus, cardiovascular implications like myocarditis, acute myocardial infarction, and acute exacerbation of heart failure (both systolic and diastolic) have been well-recognized $(4,14-17)$ [Table 5]. Based on the studies analyzed, we found that patients with COVID-19 too have a diverse cardiovascular implications ranging from acute cardiac injury to death. The incidence of acute cardiac injury ranges from $7 \%$ to $44 \%$ in different studies and the incidence were higher in patients admitted to ICU compared with non-ICU patients [Table 3]. Additionally, 
cardiovascular involvement was more commonly seen in elderly male. Patients with underlying coronary artery disease, hypertension, cardiomyopathy and other co-morbid illness are more prone to experience myocardial injury during the course of COVID-19. In these patients, superimposed viral illness damages the myocardial cells by enhancing the systemic inflammatory responses, aggravating hypoxia, and destabilizing coronary plaque. The exact pathophysiology of myocardial injury in previously healthy patients with COVID-19 infection is not fully understood. Cardiac injury can occur via direct or indirect mechanisms [Figure 2]. Direct mechanism is exhibited by infiltration of virus into myocardial cells and myocardial inflammation, resulting into cardiomyocyte death. Indirect mechanisms include respiratory failure and hypoxemia, multi-organ dysfunction, hyper-inflammation accompanied by cytokine storm, which ultimately lead to myocardial injury (18). Cytokine storm during infection possibly cause reduction in coronary blood flow, destabilization of coronary plaque and microthrombogenesis (19).

Inflammatory markers like CRP/ hs-CRP, and procalcitonin were found to be significantly elevated in patients with myocardial injury/critical patients/ICU patients; suggesting role of inflammation in COVID-19 mediated cardiac injury. Increased plasma levels of cardiac troponin, NT-proBNP, and D-dimer or new onset abnormalities in electrocardiogram or echocardiogragram can be helpful in early identification of acute cardiac injury in patients of COVID-19. Besides, cardiac troponin and NT-proBNP may play role in prognostication and possible need for intensive care in such patients. Aggressive supportive management based on prognostic indicators can improve clinical outcomes in such patients. Management of heart failure, arrhythmias, acute coronary syndrome and thrombosis is important.

The present work is, to the best of our knowledge, the first systematic review of the latest published peer reviewed studies, addressing the cardiovascular implications of COVID-19.

\section{Limitations of the review}

Our review has included limited number of available studies with small sample size. Hence, the result of our systematic review should be considered with caution. All studies included in our review were conducted in China and most of them were retrospective. Thus, our review lacks heterogeneous and diverse population. We recommend multicenter, multi-national, prospective studies be carried on cardiovascular implications of COVID-19. It is difficult to postulate myocardial injury as the sole cause of death as it may have occurred due to multi-organ dysfunction.

\section{Conclusion}

Acute cardiac injury is common in patients with COVID-19 and when it occurs, has a poor prognosis. Monitoring of myocardial injury markers and cardiac function is of utmost importance, and attention should be paid to the early identification and comprehensive management of myocardial injury in such patients.

\section{Declarations}

Ethics approval and consent to participate: Not applicable.

Consent to publish: Not applicable.

Availability of data and materials:

The datasets used and/or analyzed during the current study are available from the corresponding author on reasonable request.

\section{Competing interests:}

Authors declare no competing interests.

Funding: None

\section{Authors' contribution:}

RRP, AKY, and SM contributed to writing and reviewing data, data extraction, analysis of the results, and screening articles. RRP and AKY supervised and conceptualized the project. Specifically, all authors have (i) made substantial contributions to conception and design or acquisition of data or analysis and interpretation of data, (ii) been involved in drafting the manuscript or revising it critically for important intellectual content, (iii) given final approval of the version to be published, and (iv) agreed to be accountable for all aspects of the work in ensuring that questions related to the accuracy or integrity of any part of the work are appropriately investigated and resolved.

Acknowledgements: Not applicable.

\section{References}

1. Zhu N, Zhang D, Wang W, Li X, Yang B, Song J, et al. A novel coronavirus from patients with pneumonia in China, 2019. New England Journal of Medicine. 2020.

2. Sohrabi C, Alsafi Z, O’Neill N, Khan M, Kerwan A, Al-Jabir A, et al. World Health Organization declares global emergency: A review of the 2019 novel coronavirus (COVID-19). International Journal of Surgery. 2020. 
3. Rothan HA, Byrareddy SN. The epidemiology and pathogenesis of coronavirus disease (COVID-19) outbreak. Journal of autoimmunity. $2020: 102433$.

4. Yu C, Wong RS, Wu E, Kong S, Wong J, Yip GW, et al. Cardiovascular complications of severe acute respiratory syndrome. Postgraduate medical journal. 2006;82(964):140-4.

5. Poutanen SM, Low DE, Henry B, Finkelstein S, Rose D, Green K, et al. Identification of severe acute respiratory syndrome in Canada. New England Journal of Medicine. 2003;348(20):1995-2005.

6. Khalid M, Khan B, Al Rabiah F, Alismaili R, Saleemi S, Rehan-Khaliq AM, et al. Middle Eastern respiratory syndrome corona virus (MERS CoV): case reports from a tertiary care hospital in Saudi Arabia. Annals of Saudi medicine. 2014;34(5):396-400.

7. Moher D, Liberati A, Tetzlaff J, Altman DG, Group P. Preferred reporting items for systematic reviews and meta-analyses: the PRISMA statement. PLoS med. 2009;6(7):e1000097.

8. Cui Y, Tian M, Huang D, Wang X, Huang Y, Fan L, et al. A 55-Day-Old Female Infant Infected With 2019 Novel Coronavirus Disease: Presenting With Pneumonia, Liver Injury, and Heart Damage. The Journal of Infectious Diseases. 2020.

9. Huang C, Wang Y, Li X, Ren L, Zhao J, Hu Y, et al. Clinical features of patients infected with 2019 novel coronavirus in Wuhan, China. The Lancet. 2020 2020/02/15/;395(10223):497-506.

10. Wang D, Hu B, Hu C, Zhu F, Liu X, Zhang J, et al. Clinical Characteristics of 138 Hospitalized Patients With 2019 Novel Coronavirus-Infected Pneumonia in Wuhan, China. Jama. 2020;7(10).

11. He X, Lai J, Cheng J, Wang M, Liu Y, Xiao Z, et al. Impact of complicated myocardial injury on the clinical outcome of severe or critically ill COVID-19 patients. Zhonghua Xin Xue Guan Bing Za Zhi. 2020;48:E011-E.

12. Chen C, Yan JT, Zhou N, Zhao JP, Wang DW. [Analysis of myocardial injury in patients with COVID-19 and association between concomitant cardiovascular diseases and severity of COVID-19]. Zhonghua Xin Xue Guan Bing Za Zhi. 2020;48(0):20200225-00123.

13. Guo T, Fan Y, Chen M, Wu X, Zhang L, He T, et al. Cardiovascular implications of fatal outcomes of patients with coronavirus disease 2019 (COVID-19). JAMA cardiology. 2020.

14. Nguyen JL, Yang W, Ito K, Matte TD, Shaman J, Kinney PL. Seasonal influenza infections and cardiovascular disease mortality. JAMA cardiology. 2016;1(3):274-81.

15. Pan S, Zhang H, Li C, Wang C. Cardiac arrest in severe acute respiratory syndrome: analysis of 15 cases. Zhonghua jie he he hu xi za zhi= Zhonghua jiehe he huxi zazhi= Chinese journal of tuberculosis and respiratory diseases. 2003;26(10):602-5.

16. Li SS-I, Cheng C-w, Fu C-I, Chan Y-h, Lee M-p, Chan JW-m, et al. Left ventricular performance in patients with severe acute respiratory syndrome: a 30-day echocardiographic follow-up study. Circulation. 2003;108(15):1798-803.

17. Alhogbani T. Acute myocarditis associated with novel Middle East respiratory syndrome coronavirus. Annals of Saudi medicine. 2016;36(1):78-80.

18. Akhmerov A, Marbán E. COVID-19 and the Heart. Circulation research. 2020;126(10):1443-55.

19. Huang C, Wang Y, Li X, Ren L, Zhao J, Hu Y, et al. Clinical features of patients infected with 2019 novel coronavirus in Wuhan, China. The Lancet. 2020;395(10223):497-506.

\section{Tables}

Table 1: Study characteristics 


\begin{tabular}{|c|c|c|c|c|c|c|c|c|}
\hline Author & Year & Country & Journal & $\begin{array}{l}\text { Sample } \\
\text { size }\end{array}$ & Study design & Objectives & Inclusion criteria & $\begin{array}{l}\text { Exclusion } \\
\text { criteria }\end{array}$ \\
\hline $\begin{array}{l}\text { Wang, } \\
\text { et al. } \\
\text { (10) }\end{array}$ & $\begin{array}{l}2020 \\
\text { Feb }\end{array}$ & China & JAMA & $\begin{array}{l}\text { 138; non- } \\
\text { ICU group: } \\
\text { 102, ICU } \\
\text { group: } 36\end{array}$ & Retrospective & $\begin{array}{l}\text { To describe the } \\
\text { epidemiological } \\
\text { and clinical } \\
\text { characteristics of } \\
\text { novel } \\
\text { coronavirus- } \\
\text { infected } \\
\text { pneumonia. }\end{array}$ & $\begin{array}{l}\text { Patients with novel coronavirus- } \\
\text { infected pneumonia diagnosed } \\
\text { according to WHO interim guidance. } \\
\text { Acute cardiac injury was defined if } \\
\text { blood levels of hypersensitive } \\
\text { troponin I above the } 99 \text { th percentile } \\
\text { upper reference limit (> } 28 \mathrm{pg} / \mathrm{mL} \text { ) or } \\
\text { new abnormalities shown on } \\
\text { electrocardiography and } \\
\text { echocardiography. }\end{array}$ & NA \\
\hline $\begin{array}{l}\text { Huang, } \\
\text { et al. (9) }\end{array}$ & $\begin{array}{l}2020 \\
\text { Feb }\end{array}$ & China & Lancet & $\begin{array}{l}41 \text {; non- } \\
\text { ICU group: } \\
28, \text { ICU } \\
\text { group: } 13\end{array}$ & $\begin{array}{l}\text { Prospective, } \\
\text { observational }\end{array}$ & $\begin{array}{l}\text { To describe } \\
\text { epidemiological, } \\
\text { clinical, } \\
\text { laboratory, and } \\
\text { radiological } \\
\text { characteristics, } \\
\text { treatment, and } \\
\text { outcomes of } \\
\text { patients } \\
\text { confirmed to } \\
\text { have } 2019 \text {-novel } \\
\text { coronavirus } \\
\text { infection, and to } \\
\text { compare the } \\
\text { clinical features } \\
\text { between ICU and } \\
\text { non-ICU patients. }\end{array}$ & $\begin{array}{l}\text { Real-time RT-PCR confirmed cases of } \\
2019 \text {-novel coronavirus. Acute } \\
\text { cardiac injury was defined if blood } \\
\text { levels of hypersensitive troponin I } \\
\text { above the } 99 \text { th percentile upper } \\
\text { reference limit ( }>28 \mathrm{pg} / \mathrm{mL} \text { ) or new } \\
\text { abnormalities shown on } \\
\text { electrocardiography and } \\
\text { echocardiography. }\end{array}$ & NA \\
\hline $\begin{array}{l}\text { Chen, et } \\
\text { al.(12) }\end{array}$ & $\begin{array}{l}2020 \\
\text { March }\end{array}$ & China & $\begin{array}{l}\text { Chinese } \\
\text { J Card } \\
\text { Dis }\end{array}$ & $\begin{array}{l}\text { 150; non- } \\
\text { critical } \\
\text { group: } 126, \\
\text { critical } \\
\text { group: } 24\end{array}$ & Retrospective & $\begin{array}{l}\text { Analysis of } \\
\text { myocardial injury } \\
\text { and } \\
\text { cardiovascular } \\
\text { disease in } \\
\text { critically ill } \\
\text { patients with new } \\
\text { coronavirus } \\
\text { pneumonia. }\end{array}$ & $\begin{array}{l}\text { Patients of new Coronavirus } \\
\text { pneumonia clinically typed according } \\
\text { to the "Diagnosis and Treatment } \\
\text { Scheme for New Coronavirus Infected } \\
\text { Pneumonia (Trial Version } 6) " . \\
\text { Critically ill patients were defined by } \\
\text { one of the following conditions: } \\
\text { respiratory failure requiring } \\
\text { mechanical ventilation, presence of } \\
\text { shock, and multi-organ failure } \\
\text { requiring ICU admission. Acute } \\
\text { cardiac injury was defined if blood } \\
\text { levels of hypersensitive troponin I } \\
\text { above the } 99 \text { th percentile upper } \\
\text { reference limit (>26.3 ng/L). }\end{array}$ & $\begin{array}{l}\text { Patients of } \\
\text { acute } \\
\text { myocardial } \\
\text { infarction } \\
\text { diagnosed by } \\
\text { clinical chest } \\
\text { pain symptoms } \\
\text { and ECG } \\
\text { changes. }\end{array}$ \\
\hline $\begin{array}{l}\text { Xingwei, } \\
\text { et al. } \\
\text { (11) }\end{array}$ & $\begin{array}{l}2020 \\
\text { March }\end{array}$ & China & $\begin{array}{l}\text { Chinese } \\
\text { J Card } \\
\text { Dis. }\end{array}$ & $\begin{array}{l}54 ; \text { Group } \\
\text { with } \\
\text { myocardial } \\
\text { injury: } 24, \\
\text { Group } \\
\text { without } \\
\text { myocardial } \\
\text { injury: } 30\end{array}$ & Retrospective & $\begin{array}{l}\text { To know the } \\
\text { impact of } \\
\text { complicated } \\
\text { myocardial injury } \\
\text { on the clinical } \\
\text { outcome of } \\
\text { severe or critically } \\
\text { ill COVID-19 } \\
\text { patients. }\end{array}$ & $\begin{array}{l}\text { (1) } 2019 \text {-nCoV nucleic acid test } \\
\text { positive cases, and meeting the } \\
\text { diagnostic criteria for severe / } \\
\text { critically severe cases; } \\
\text { (3) Critical and severe COVID-19 is } \\
\text { defined in accordance with any of the } \\
\text { following: (a) respiratory failure } \\
\text { requiring mechanical ventilation; (b) } \\
\text { shock; (c) combined with other organ } \\
\text { failure requiring ICU monitoring and } \\
\text { treatment (2) Complete clinical data } \\
\text { and at least two cardiac troponin test } \\
\text { results. } \\
\text { 3. Myocardial injury was defined as } \\
\text { blood levels of myocardial troponin } \\
\geq 3 \text { times the upper reference limit } \\
\text { (34.2 ng / L). }\end{array}$ & $\begin{array}{l}\text { (1) Non-2019- } \\
\text { nCoV infection } \\
\text { confirmed } \\
\text { cases; (2) } \\
\text { patients with } \\
\text { acute } \\
\text { myocardial } \\
\text { infarction, } \\
\text { decompensated } \\
\text { heart failure, } \\
\text { and chronic } \\
\text { renal failure; (3) } \\
\text { missing clinical } \\
\text { data. }\end{array}$ \\
\hline $\begin{array}{l}\text { Cui, et } \\
\text { al (8) }\end{array}$ & $\begin{array}{l}2020 \\
\text { March }\end{array}$ & China & $\begin{array}{l}J \operatorname{lnf} \\
\text { Dis. }\end{array}$ & 1 & Case report & $\begin{array}{l}\text { To highlight that } \\
\text { child with COVID- } \\
19 \text { can also } \\
\text { present with } \\
\text { multiple organ } \\
\text { damage and } \\
\text { rapid disease } \\
\text { changes. }\end{array}$ & NA & NA \\
\hline $\begin{array}{l}\text { Guo, et } \\
\text { al. (13) }\end{array}$ & $\begin{array}{l}2020 \\
\text { March }\end{array}$ & China & JAMA & $\begin{array}{l}\text { 187; Group } \\
\text { normal } \\
\text { cardiac } \\
\text { troponin: } \\
\text { 135, Group } \\
\text { with } \\
\text { elevated } \\
\text { cardiac } \\
\text { troponin: } \\
\text { 52 }\end{array}$ & Retrospective & $\begin{array}{l}\text { To evaluate the } \\
\text { association of } \\
\text { underlying } \\
\text { cardiovascular } \\
\text { disease and } \\
\text { myocardial injury } \\
\text { with fatal } \\
\text { outcomes in } \\
\text { patients with } \\
\text { COVID-19. }\end{array}$ & $\begin{array}{l}\text { Patients with COVID-19 who were } \\
\text { diagnosed as per WHO interim } \\
\text { guideline, and who were either treated } \\
\text { and discharged or died during } \\
\text { hospitalization. Myocardial injury } \\
\text { was defined by serum levels of } \\
\text { troponin T were above the 99th } \\
\text { percentile upper reference limit. }\end{array}$ & NA \\
\hline
\end{tabular}


ICU: Intensive Care Unit

NA: Not available

nCoV: novel coronavirus

RT-PCR: Reverse Transcriptase- Polymerase Chain Reaction

WHO: World Health Organization

Table 2: Baseline characteristics and co-morbidities of the patients

\begin{tabular}{|c|c|c|c|c|c|c|c|c|c|c|c|}
\hline Author & Age (years) & $\begin{array}{l}\text { Male } \\
\text { percentage }\end{array}$ & $\begin{array}{l}\text { Hypertension } \\
(\%)\end{array}$ & $\begin{array}{l}\text { Cardiovascular } \\
\text { disease (\%) }\end{array}$ & $\begin{array}{l}\text { Diabetes } \\
(\%)\end{array}$ & $\begin{array}{l}\text { Malignancy } \\
(\%)\end{array}$ & $\begin{array}{l}\text { Cerebrovascular } \\
\text { disease (\%) }\end{array}$ & $\begin{array}{l}\text { COPD } \\
(\%)\end{array}$ & $\begin{array}{l}\text { CKD } \\
(\%)\end{array}$ & $\begin{array}{l}\text { CLD } \\
(\%)\end{array}$ & $\begin{array}{l}\text { HIV } \\
\text { infec } \\
(\%)\end{array}$ \\
\hline $\begin{array}{l}\text { Wang, } \\
\text { et al. } \\
\text { (10) }\end{array}$ & $\begin{array}{l}\text { Median: 56; } \\
\text { non-ICU } \\
\text { group: } 51, \text { ICU } \\
\text { group: } 66\end{array}$ & 54.3 & 31.2 & 14.5 & 10.1 & 7.2 & 5.1 & 2.9 & 2.9 & 2.9 & 1.4 \\
\hline $\begin{array}{l}\text { Huang, } \\
\text { et al.(9) }\end{array}$ & $\begin{array}{l}\text { Median: } 49 ; \\
\text { non-ICU } \\
\text { group: } 49, \text { ICU } \\
\text { group: } 49\end{array}$ & 73 & 15 & 15 & 20 & 2 & NA & 2 & NA & 2 & NA \\
\hline $\begin{array}{l}\text { Chen, et } \\
\text { al.(12) }\end{array}$ & $\begin{array}{l}\text { Mean: } 59 ; \\
\text { non-critical } \\
\text { group:57.1, } \\
\text { critical } \\
\text { group: } 68.5\end{array}$ & 56 & 32.6 & 6 & 13.3 & 2 & NA & NA & 1.3 & NA & NA \\
\hline $\begin{array}{l}\text { Xingwei, } \\
\text { et al. } \\
\text { (11) }\end{array}$ & $\begin{array}{l}\text { Median: 68; } \\
\text { Group without } \\
\text { myocardial } \\
\text { injury: } 67 \\
\text { Group with } \\
\text { myocardial } \\
\text { injury: } 69.5\end{array}$ & 63 & 44.4 & 14.8 & 24.1 & 3.7 & 5.6 & 3.7 & NA & NA & NA \\
\hline $\begin{array}{l}\text { Cui, et } \\
\text { al (8) }\end{array}$ & 55 days & Female & NA & NA & NA & NA & NA & NA & NA & NA & NA \\
\hline $\begin{array}{l}\text { Guo, et } \\
\text { al. (13) }\end{array}$ & $\begin{array}{l}\text { Mean: } 58.5 ; \\
\text { Group normal } \\
\text { cardiac } \\
\text { troponin:53.53 } \\
\text {, Group with } \\
\text { elevated } \\
\text { cardiac } \\
\text { troponin: } 71.4\end{array}$ & 48.7 & 32.6 & 15.5 & 15 & 7 & NA & 2.1 & 3.2 & NA & NA \\
\hline
\end{tabular}

ICU: Intensive Care Unit

NA: Not available

Table 3: Cardiovascular complications associated with COVID-19 


\begin{tabular}{|c|c|c|c|c|c|}
\hline Author & Complications & All patients (\%) & ICU patients (\%) & Non-ICU patients (\%) & $\mathrm{p}$-value \\
\hline \multirow[t]{4}{*}{ Wang, et al. (10) } & Shock & 8.7 & 30.6 & 1 & $<0.001$ \\
\hline & Acute cardiac injury & 7.2 & 22.2 & 2 & $<0.001$ \\
\hline & Arrhythmia & 16.7 & 44.4 & 6.9 & $<0.001$ \\
\hline & Death & 4.3 & NA & NA & NA \\
\hline \multirow[t]{3}{*}{ Huang, et al. (9) } & Shock & 7 & 23 & 0 & 0.027 \\
\hline & Acute cardiac injury & 12 & 31 & 4 & 0.017 \\
\hline & Death & 15 & 38 & 4 & NA \\
\hline \multirow[t]{2}{*}{ Chen, et al. (12) } & Acute cardiac injury & 7.1 & 62.5 & 5.6 & $<0.001$ \\
\hline & Death & 7.3 & 41.7 & 0.8 & $<0.001$ \\
\hline \multirow[t]{2}{*}{ Xingwei, et al. (11) } & Acute cardiac injury & 44.4 & NA & NA & NA \\
\hline & Death & 48.1 & $75^{a}$ & $26.7^{b}$ & 0.001 \\
\hline Cui, et al (8) & Death & Patient recovered & NA & NA & NA \\
\hline \multirow[t]{3}{*}{ Guo, et al. (13) } & Acute cardiac injury & 27.8 & NA & NA & NA \\
\hline & Arrhythmia & 5.9 & $17.3^{c}$ & $1.5^{d}$ & $<0.001$ \\
\hline & Death & 23 & $59.6^{c}$ & $8.9^{d}$ & $<0.001$ \\
\hline
\end{tabular}

${ }^{a}$ Group with myocardial injury

${ }^{b}$ Group without myocardial injury

${ }^{\mathrm{c}}$ Group with elevated cardiac troponin T

${ }^{\mathrm{d}}$ Group without elevated cardiac troponin T

NA: Not available

Table 4: Inflammatory and cardiac biomarkers of the patients 


\begin{tabular}{|c|c|c|c|c|c|c|c|}
\hline Author & Parameters, & $\begin{array}{l}\text { Normal } \\
\text { range }\end{array}$ & All patients & & $\begin{array}{l}\text { Patients with severe } \\
\text { disease or non-ICU patients }\end{array}$ & $\begin{array}{l}\text { Patients with very severe } \\
\text { disease or ICU patients }\end{array}$ & $\begin{array}{l}\mathrm{p}- \\
\text { value }\end{array}$ \\
\hline \multirow[t]{4}{*}{$\begin{array}{l}\text { Wang, et } \\
\text { al.(10) }\end{array}$} & CPK-MB (U/L) & $<25$ & 14 & & 13 & 18 & $\begin{array}{l}< \\
0.001\end{array}$ \\
\hline & $\begin{array}{l}\text { Procalcitonin }(\mathrm{ng} / \mathrm{mL}) \\
\geq 0.05 \text {, No. }(\%)\end{array}$ & $<0.05$ & $49(35.5)$ & & $22(21.6)$ & $27(75)$ & $\dot{c}_{0.001}$ \\
\hline & Troponin I (pg/mL) & $<26.2$ & 6.4 & & 5.1 & 11 & 0.004 \\
\hline & D-dimer (mg/L) & $0-500$ & 203 & & 166 & 414 & $<0.001$ \\
\hline \multirow[t]{4}{*}{$\begin{array}{l}\text { Huang, et } \\
\text { al. (9) }\end{array}$} & CPK (U/L) & $\leq 185$ & $132 \cdot 5$ & $0 \cdot 31$ & 133 & 132 & 0.31 \\
\hline & $\begin{array}{l}\text { Procalcitonin } \\
(\mathrm{ng} / \mathrm{mL}) \geq 0.05 \text {, No. }(\%)\end{array}$ & $<0.05$ & $3(8)$ & & 0 & $3(25)$ & NA \\
\hline & $\begin{array}{l}\text { Troponin I }(\mathrm{pg} / \mathrm{mL}),>28 \\
\text { (99th percentile) }\end{array}$ & NA & $5 / 41(12 \%)$ & & $1 / 28(4 \%)$ & 4/13 (31\%) & 0.017 \\
\hline & D-dimer (mg/L) & NA & 0.5 & & 0.5 & 2.4 & 0.0042 \\
\hline \multirow{3}{*}{$\begin{array}{l}\text { Chen, et al. } \\
\text { (12) }\end{array}$} & hsCRP (mg/L) & NA & NA & & 30.9 & 84.9 & $<0.001$ \\
\hline & NT-proBNP (ng / L) & NA & NA & & 83 & 1030 & $<0.001$ \\
\hline & Troponin I (ng/L) & NA & NA & & 4.5 & 68.5 & $<0.001$ \\
\hline \multirow{2}{*}{$\begin{array}{l}\text { Xingwei, et } \\
\text { al. (11) }\end{array}$} & $\mathrm{CRP}(\mathrm{mg} / \mathrm{L})$ & 10 & NA & & $62.9^{\mathrm{b}}$ & $135^{a}$ & 0.007 \\
\hline & NT-proBNP (ng/L) & $<486$ & NA & & $201^{b}$ & $971^{\text {a }}$ & $<0.001$ \\
\hline \multirow{4}{*}{$\begin{array}{l}\text { Cui, et al } \\
\text { (8) }\end{array}$} & $\mathrm{CRP}(\mathrm{mg} / \mathrm{L})$ & $0-5$ & 0.56 & & NA & NA & NA \\
\hline & Procalcitonin $(\mathrm{ng} / \mathrm{mL})$ & $0-0.046$ & 0.15 & & NA & NA & NA \\
\hline & CPK-MB (U/L) & $0-25$ & 46 & & NA & NA & NA \\
\hline & Troponin I (ugm/L) & $\begin{array}{l}0- \\
0.0156\end{array}$ & 0.025 & & NA & NA & NA \\
\hline \multirow{7}{*}{$\begin{array}{l}\text { Guo, et al. } \\
(13)\end{array}$} & $\mathrm{hsCRP}(\mathrm{mg} / \mathrm{dL})$ & NA & 4.04 & & $3.13^{d}$ & $8.55^{\mathrm{c}}$ & $<0.001$ \\
\hline & Procalcitonin (ng/mL) & NA & 0.08 & & $0.05^{d}$ & $0.21^{\mathrm{c}}$ & $<0.001$ \\
\hline & Globulin (g/L) & NA & 27.7 & & $27.4^{d}$ & $29.7^{c}$ & $<0.001$ \\
\hline & CPK-MB (ng/mL) & NA & 1.14 & & $0.81^{d}$ & $3.34^{\mathrm{c}}$ & $<0.001$ \\
\hline & Myoglobulin (ug/L) & NA & 38.5 & & $27.2^{d}$ & $128.7^{c}$ & $<0.001$ \\
\hline & NT-proBNP (pg/mL) & NA & 268.4 & & $141.4^{d}$ & $817.4^{c}$ & $<0.001$ \\
\hline & d-dimer (ugm/mL) & NA & 0.43 & & $0.29^{d}$ & $3.85^{c}$ & $<0.001$ \\
\hline
\end{tabular}

CPK-MB: Creatine phosphokinase myocardial band

CPK: Creatine phosphokinase

hsCRP: Hypersensitive C-reactive protein

NT-proBNP: N-terminal-pro brain natriuretic peptide

a Group with myocardial injury

${ }^{b}$ Group without myocardial injury

${ }^{c}$ Group with elevated cardiac troponin T

${ }^{d}$ Group without elevated cardiac troponin T 


\begin{tabular}{|lllll|}
\hline Outbreak & Author & Journal & $\begin{array}{l}\text { Sample } \\
\text { size }\end{array}$ & Cardiovascular implications \\
& Yu, et al. (4) & BMJ & 121 & Hypotension, tachycardia, bradycardia, cardiomegaly, and arrhythmia \\
& $\begin{array}{l}\text { Pan, et al. } \\
(15)\end{array}$ & $\begin{array}{l}\text { Chinese J Tuberculosis and } \\
\text { Respiratory Dis }\end{array}$ & 15 & Cardiac arrest \\
\cline { 2 - 3 } & Li, et al (16) & Circulation & 46 & $\begin{array}{l}\text { Sub-clinical diastolic impairment without systolic involvement on } \\
\text { echocardiography }\end{array}$ \\
\hline MERS & $\begin{array}{l}\text { Alhogbani } \\
(17)\end{array}$ & Annals Saudi Med. & 1 & Acute myocarditis and acute-onset heart failure \\
\hline
\end{tabular}

SARS: Severe Acute Respiratory Syndrome

MERS: Middle East Respiratory Syndrome

BMJ: British Medical Journal

\section{Figures}

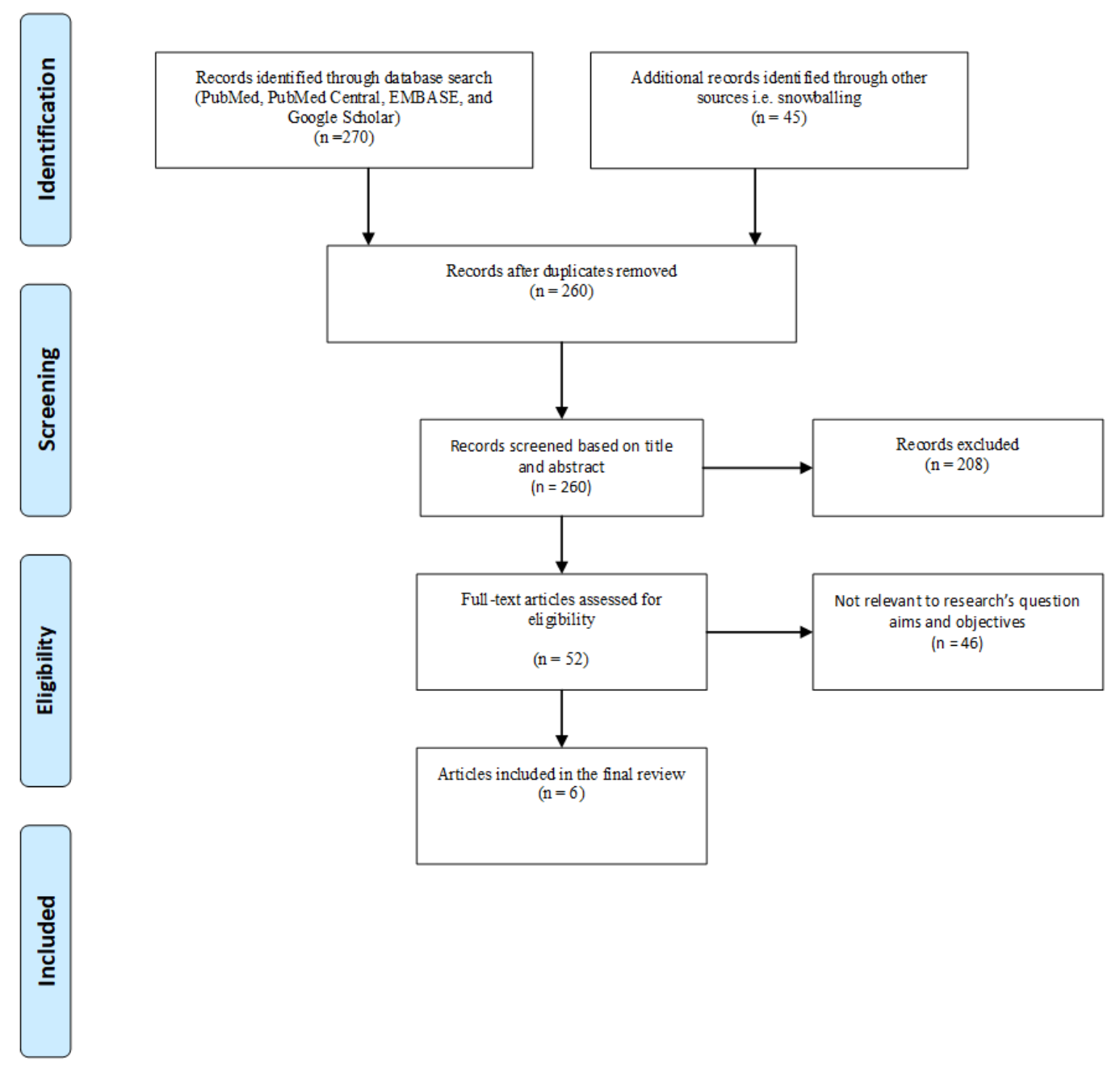

Figure 1

PRISMA diagram detailing the study identification and selection process 


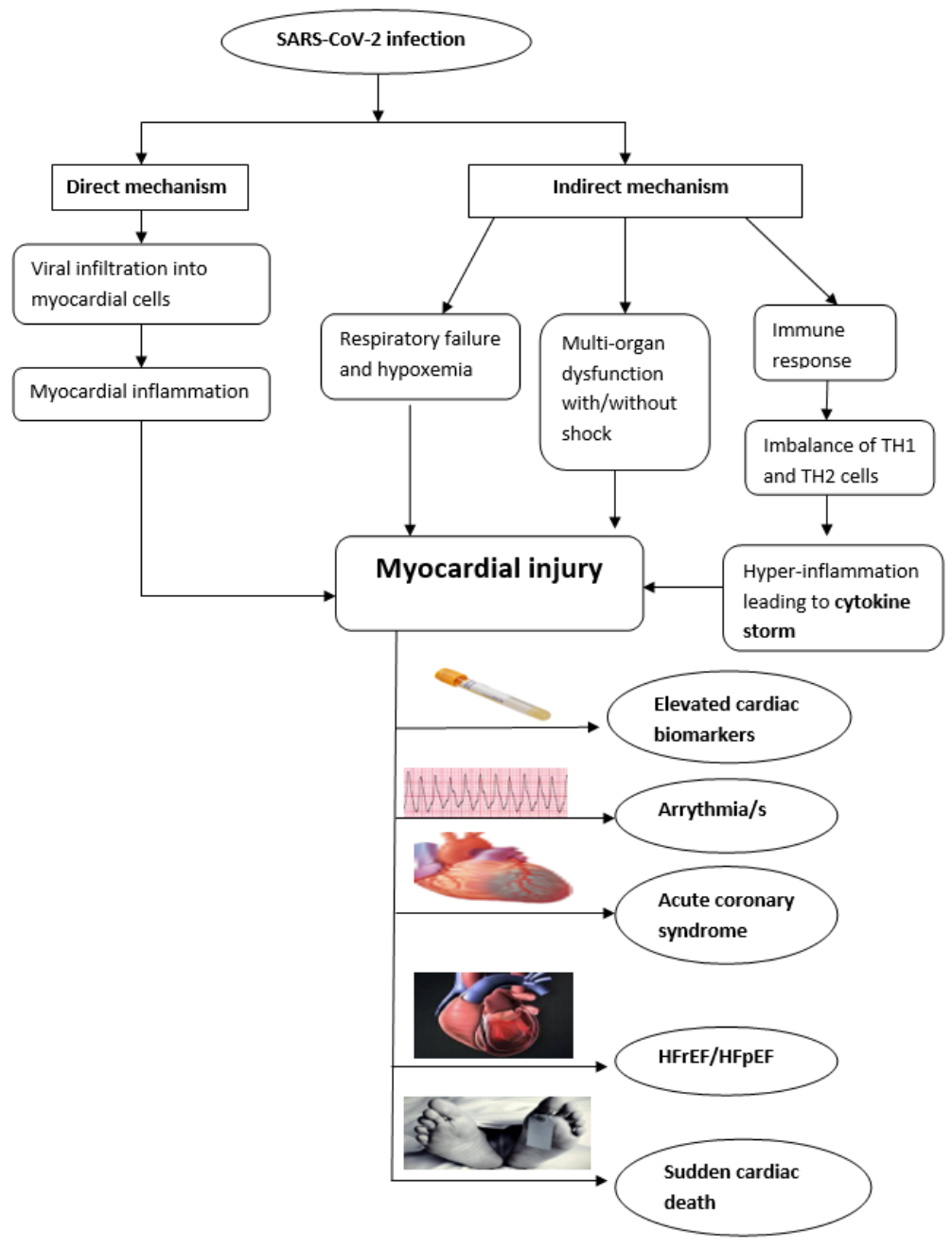

\section{Figure 2}

Pathophysiology of myocardial injury in patients with COVID-19 